\title{
GENETIC MECHANISMS OF METHICILLIN RESISTANCE IN STAPHYLOCOCCUS AUREUS (MRSA) AND ITS CAPACITY OF TRANSMISSION: A BRIEF REVIEW
}

\author{
Maja Velhner ${ }^{1^{*}}$, Gordana Kozoderović ${ }^{2}$ \\ Ljiljana Suvajdžićc ${ }^{3}$, Dalibor Todorović ${ }^{1}$ Jelena Petrović ${ }^{1}$ \\ ${ }^{1}$ Scientific Veterinary Institute "Novi Sad", Novi Sad, Serbia \\ ${ }^{2}$ Faculty of Education in Sombor, Department of Natural Sciences \\ and Management in Education, University of Novi Sad, Serbia \\ ${ }^{3}$ Faculty of Medicine, Department of Pharmacy, \\ University of Novi Sad, Novi Sad, Serbia
}

Abstract

Methicillin-resistant Staphylococcus aureus is one of the most important human pathogens. These bacteria have the ability to colonize animals and cross species barriers. Three major groups of MRSA strains have emerged. Healthcare associated MRSA and community acquired MRSA strains have potential to spread worldwide and often persist in hospitals and communities as clonal strains. The livestock-associated MRSA has been isolated from healthy human carriers but also from infected patients all around the world. Molecular typing of staphylococcal cassette chromosome mec (SCCmec), multilocus sequence typing in combination with pulse field gel electrophoresis and spa typing are most frequently used for genetic characterization of MRSA strains. The community-acquired MRSA strains are capable of producing Panton Valentine leukocidin (PVL) cytotoxin which is their major virulence determinant. MRSA strains possess a number of virulence factors that are common in other bacteria and it is still not entirely explained which virulence factors or mechanisms of their regulation are important for the pathogenic potential, persistence in the environment or the ability to cause detrimental infection in patients. Recently, as a contribution to the progress of molecular biology, peculiar mechanisms of genetic regulation of virulence genes have been discovered and their role in pathogenesis of infection and epidemiology of MRSA has been studied.

Key words: MRSA, pigs, humans, epidemiology, mecA, PVL

${ }^{1 *}$ Corresponding author: maja@niv.ns.ac.rs 


\title{
GENETIČKI MEHANIZMI REZISTENCIJE NA METICILIN KOD STAPHYLOCOCCUS AUREUS (MRSA) I NJIHOVO PRENOŠENJE: KRATAK PREGLED
}

\author{
Maja Velhner', Gordana Kozoderović \\ Ljiljana Suvajdžić ${ }^{3}$, Dalibor Todorović ${ }^{1}$, Jelena Petrović ${ }^{1}$ \\ ${ }^{1}$ Naučni institut za veterinarstvo "Novi Sad", Novi Sad, Srbija, \\ ${ }^{2}$ Učiteljski fakultet u Somboru, Departman za prirodne nauke i menadžment \\ u obrazovanju, Univerzitet u Novom Sadu, Novi Sad, Srbija \\ ${ }^{3}$ Medicinski fakultet, Departman za farmaciju, \\ Univerzitet u Novom Sadu, Novi Sad, Srbija
}

\section{Kratak sadržaj}

Staphylococcus aureus koji poseduje rezistenciju na meticilin, jedan je od najvažnijih humanih patogena. Ovi mikroorganizmi imaju sposobnost da koloniziraju životinje i da prelaze barijeru između vrsta. Do sada su utvrđene tri glavne grupe MRSA. MRSA sojevi koji su bolničkog ili vanbolničkog porekla rašireni su u celom svetu i često perzistiraju klonalno. MRSA poreklom od životinja su takođe nađeni i kod ljudi koji su latentno inficirani i kod inficiranih pacijenta u celom svetu. Molekularna tipizacija hromozomske kasete mec (SCCmec), sekvenciranje većeg broja genetičkih lokusa u kombinaciji sa elektroforezom u pulsnom polju, kao i spa tipizacija, najčešće se koriste za genetičku karakterizaciju MRSA. Vanbolnički MRSA sojevi iz zajednice imaju sposobnost da produkuju Panton Valentin leukocidin (PVL) citotoksin koji je ujedno i najvažnija determinanta njihove virulencije. MRSA poseduju mnogobrojne faktore virulencije koje se nalaze i kod drugih bakterija i još uvek nije u potpunosti objašnjeno koji su geni virulencije ili mehanizmi njihove regulacije važni za patogeni potencijal, perzistiranje u životnoj sredini ili u nekim slučajevima, za nastanak po život opasnih infekcija ljudi. Paralelno sa razvojem molekularne biologije, naučnici otkrivaju specifične mehanizme genetske regulacije faktora virulencije i istraživanje njihove uloge u patogenezi i epidemiologiji infekcija koje izazivaju MRSA sojevi.

Ključne reči: MRSA, svinje, ljudi, epidemiologija, mecA, PVL 


\section{Introduction}

Methicillin is semisynthetic penicillin which was discovered in 1959 and it was used for the therapy of infections caused by Staphylococcus aureus which are resistant to penicillin and extended spectrum beta-lactam antibiotics. However, soon after methicillin had been introduced into clinical practice, resistance occurred and healthcare-associated MRSA (HA-MRSA) became one of the most important nosocomial pathogens worldwide (Gordon and Lowy, 2008). The methicillin resistance gene mecA that encodes a penicillin-binding protein (PBP2A) is integrated in staphylococcal cassette chromosome mec (SC$\mathrm{Cmec}$ ) locus. The mobile genetic element SCCmec is composed of the terminal inverted and direct repeats and the junkyard region $(\mathrm{J})$. Major components of the cassette are mecA gene complex and its regulatory elements include gene encoding recombinases ( $c c r$ ) which are involved in the integration or excision of the cassette into the chromosome and subsequent intra and interspecies transmission. The cassette is classified into types I, II, III, IV, V (based on mec and $s c c$ genes sequences) and subtypes (based on differences determined in junkyard region). In hospital acquired MRSA (HA- MRSA) this large SCCmec cassette is represented by types I, II and III. Community associated infections with methicillin resistant $S$. aureus (CA- MRSA) strains also became a major threat to the public health. The CA-MRSA has a smaller SCCmec cassette type $\mathrm{IV}$ and $\mathrm{V}$ and a smaller number of the resistance genes are incorporated inside cassette (Zhang et al., 2005).

Genetic analysis of MRSA strains, especially of the SCCmec cassette, is important from the epidemiological standpoint. Polymerase chain reaction or multiplex PCR are used as traditional typing methods for the characterization of the structural types of mec elements (Oliveira and Lencastre, 2002). The multilocus sequence typing (MLST) has also become a prestigious method for genetic analysis of the entire genome of MRSA strains and has helped in providing the newest nomenclature of MRSA (Zhang et al., 2005). The identification of the genes encoding exotoxins, present additional tool in the analysis of the MRSA isolates. Panton Valentine leukocidin genes (lukS- $P V$ and $l u k F-P V$ ), which encode cytotoxin are of particular interest. PVL cytotoxin causes leukocytes destruction and tissue necrosis. The PVL genes are most often found in CA- MRSA strains and much less frequently in HA-MRSA. The $\gamma$ hemolysin variant and Lekocidin E-D gene, as well as other genes encoding exotoxins, were detected evenly in HA and CA-MRSA strains, while sec and sek genes were found only in CA-MRSA strains in a cohort study of patients with MRSA infection in Minnesota in the year 2000 (Naimi et al., 2003). 
Important discriminatory tool for MRSA is single-locus DNA sequencing of the spa gene (encoding A protein) (Frenay et al., 1994, Frenay et al., 1996). The spa gene is represented by a number of repeats that are susceptible to spontaneous mutations, loss or insertion or repeat exchange. A software program was applied for the first time for the spa typing by Harmsen et al. (2003) who have studied spa types of the MRSA isolates from a single hospital at the Würzburg University Clinic, Germany. Only single unrepeated isolates (first isolate from a patient) were used for genotyping during the study period. Software has been designed to use internet database for the automatic recognition of the spa type after entering the sequence data. This method is not as expensive as MLST and it is not as time consuming as PFGE. However, in order to determine genetic differences in MRSA isolates the best choice is to combine the spa typing with MLST and PFGE. Particular spa types were found to be associated with the specific MLST clones in regard to resistotype and colony morphology on blood agar. Hence, bacteriological and genetic methods combined are preferable for the distinguishing of the MRSA epidemic clones (Harmsen et al., 2003).

\section{LIVESTOCK-ASSOCIATED MRSA (LA-MRSA)}

Livestock-associated MRSA human infection was reported in 2004 in the Netherlands for the first time. A case study included a young girl and other family members who were involved in pig farming as well as two patients, and a nurse. All isolates from the outbreak were untypeable by PFGE using SmaI restriction enzyme. However, a single random amplified polymorphic DNA analysis and the single spa type (Spa-type 108) have shown that pig associated MRSA had caused the infection of humans (Voss et al., 2003). This was a first report of a transmission from animals to humans which was immediately followed by a number of reports about the infection of humans with livestock-associated MRSA (LA-MRSA) all around the world (Burns et al., 2014, Chuang et al., 2015, van Cleef et al., 2011, Fang et al., 2014, Golding et al., 2010, Huang et al., 2014., Patchanee et al., 2014). The majority of the LA-MRSA isolates belonged to the clonal lineage ST 398. Other specific features included the lack of PVL toxin and the absence of the SmaI restriction site. Several spy types were found in LA-MRSA strains which are also showing peculiar genetic differences and ability to spread among humans causing serious health disorders (Huijsdens et al., 2006). People living close to farms are more often exposed to LA-MRSA and may become silent carriers. However, LA-MRSA infection in patients that had not had direct contact with animals was also reported, im- 
plicating different transmission pathways. Healthcare facilities may become an important place where infection may occur through contact with objects, contaminated foods and humans. Air borne transmission in places highly populated with pigs, also present an additional risk for spreading of MRSA in the environment (Deiters et al., 2015).

\section{TWO WAY ADAPTATION OF MRSA}

Over the years MRSA has shown capacity to transfer from humans to cattle and to other animal species and has become the most prevalent in pig herds. Soon after the initial establishment in animals, MRSA has found the way back to humans. However, MRSA is constantly changing and its different invasion capacity and pathogenicity mechanisms are recognized. Much work has been done to compare various MRSA strains of human and livestock origin utilizing different scientific approaches including phenotypic and genotypic experimental designs.

\section{PATHOGENESIS AND EPIDEMIOLOGY OF MRSA}

It was established that MRSA originate from MSSA strains after successful receipt of the SCCmec element, early after methicillin was introduced to clinical practice. MRSA has many virulence factors which are common to other bacteria. When inducing clinical infection, MRSA recruits specific genetic elements to enable adherence to the epithelial and endothelial cells. These strains have profound capacity for biofilm formation and evasion of immune responses of the host. Initial colonization ability is enabled by the early expression of the so called "microbial surface components recognizing adhesive matrix molecules"- MSCRAMMs, while toxins facilitate their further spread. Due to their specific pathogenic properties, it can cause recurrent infections. The HA-MRSA strains are often clonal and widespread all around the world. They become established in the hospital environment due to the number of virulence factors and multidrug resistant phenotype. However, the occurrence of MRSA infections with fatal outcome was recorded in the year 1990, in humans without healthcare contact or other risk factors for MRSA. Two well established clones of CA-MRSA in the USA are USA400 and USA300 (SCCmecIV) which can cause fatal necrotizing pneumonia or skin infections in patients. Infection with USA400 and USA300 was also identified in individuals with no history of hospitalization (Gordon and Lowy, 2008). Therefore, CA-MRSA became widespread in hospitals and crossed roads with the HA-MRSA strains. 
In epidemiological studies several key points are important in determining the type of MRSA strains: the onset of the infection, recent or longer admission to hospital, prior infections, genetic characterization and clinical symptoms. Data collected from a single patient history or from an outbreak are important in epidemiological studies and have to be considered for establishing antibiotic therapy (David and Daum, 2010).

\section{INVADING CAPACITIES OF MRSA IN VITRO}

MRSA strains have different invading capacity in vitro. It was shown that LA-MRSA decreased potential of adherence to epithelial and endothelial cells with no apparent difference between the hosts (human or pig) comparing to HA and CA-MRSA strains. However, the specific spa type (the spa type t108) showed increased adhesive response comparing to spa types t011 and t034. Binding capacity to human and bovine plasma fibronectin was less efficient in LA-MRSA comparing to HA and CA MRSA strains, except for the spa type t108, which had a better binding ability comparing to other LA-MRSA strains. Invasiveness in embryonic kidney cells was more prominent in HA and CA-MRSA except for LA-MRSA spa type t108 which showed even higher invasiveness compared to HA and CA-MRSA. The spa type t108 was also less effectively phagocytosed by human polymorphonuclear leukocytes comparing to other LA-MRSA spa types and also comparing to some CA-MRSA strains. The evasion of this type of immune response may be driven by fibrin clots formation to which bacteria becomes encased and to which it binds, but clear differences between the molecular mechanisms were not identified in MRSA strains. In addition, LA-MRSA strains are forming capsules that protect MRSA from opsonization by a macrophage. This property is not related only to the spa type t108, rather it is a common feature among various spa types in human and animal MRSA strains. Other immune evasion mechanisms that have been studied so far often produced conflicting results or could not be adequately extrapolated on various MRSA isolates. However, LA-MRSA is found to exhibit strong toxic effect on epithelial cells by releasing eukaryotic lactate-dehydrogenase (LDH) enzyme. The upregulation of genes $h l b$ and hla (encoding $\beta$-hemolysin) is also pronounced in LA- MRSA strain and it is comparable to the alpha-hemolysin producer USA300-LAC. Therefore, LA-MRSA has a clear pathogenic potential for humans quite similar to HA and CA-MRSA and presents an important pathogen all around the globe (Ballhausen et al., 2014). 


\section{CONCLUSION}

MRSA is constantly changing and over decades has developed new features essential for their successful adaptation to new environments. Studies which aim to identify major genetic elements in MRSA and mechanism of their regulation, contribute in development of new or improved drugs which are important to reduce infection of humans. Agricultural use of antibiotics has to be minimized in the future which will in part "close the door" for future development of new antimicrobial resistance mechanism in bacteria.

\section{ACKNOWLEDGMENT}

This work has been funded by the Ministry of Education, Science and Technological Development of the Republic of Serbia, Project number TR 31071.

\section{REFERENCES:}

1. Ballhausen B., Jung P., Kriegeskorte A., Makgotlho PE., Ruffing U., von Müller L., Köck R., Peters G., Herrmann M., Ziebuhr W., Becker K., Bischoff M.: LA-MRSA CC398 differ from classical community acquiredMRSA and hospital acquired-MRSA lineages: functional analysis of infection and colonization process. International Journal of Medical Microbio$\log y$ 304, 777-786, 2014.

2. Burns A., Shore AC., Brennan GI., Coleman DC., Egan J., Fanning S., Galligan MC., Gibbons JF., Gutierrez M., Malhotra-Kumar S., Markey BK., Sabirova JS., Wang J., Leonard FC.: A longitudinal study of Staphylococcus aureus colonization in pigs in Ireland. Veterinary Microbiology, 174, 504-513, 2014.

3. Chuang YY, Huang YC: Livestock-associated meticillin-resistant Staphylococcus aureus in Asia. An emerging issue? International Journal of Antimicrobial Agents, 45, 334-340, 2015.

4. van Cleef BAGL., Monnet DL., Voss A., Krziwanek K., Allerberger F., Struelens M., Zemlickova H., Skov RL., Vuopio-Varkila J., Cuny C., Friedrich AW., Spiliopoulou I., Pászti J., Hardardottir H., Rossney A., Pan A., Pantosti A., Borg M., Grundmann H., Mueller-Premru M., Olsson-Liljequist B., Widmer A., Harbarth S., Schweiger A., Unal S., Kluytmans JAJW.: Livestock-associated methicillin-resistant Staphylococcus aureus in -humans, Europe. Emerging Infectious Diseases 17, 502-505, 2011.

5. David MZ., Daum RS.: Community-associated methicillin-resistant Staphylococcus aureus: epidemiology and clinical consequences of an 
emerging epidemic. Clinical Microbiology Reviewes, 23, 616-687, 2010.

6. Deiters C., Günnewig V., Friedrich AW., Mellmann A., Köck R.: Are cases of Methicillin-resistant Staphylococcus aureus clonal complex (CC) 398 among humans still livestock-associated? International Journal of Medical Microbiology, 305, 110-113, 2015.

7. Fang HW., Chiang PH., Huang YC.: Livestock-associated methicillin-resistant Staphylococcus aureus ST9 in pigs and related personnel in Taiwan. PlosOne, 9, 2, e88826. doi:10.1371/journal.pone.0088826.

8. Frénay HME., Theelen JPG., Schouls LM., Vandenbroucke-Grauls CMJE., Verhoef J., van Leeuwen WJ., Mooi FR.: Discrimination of epidemic and nonepidemic methicillin-resistant Staphylococcus aureus strains on the basis of protein A gene polymorphism. Journal of Clinical Microbiology, 32, 846-847, 1994.

9. Frénay HME., Bunschoten AE., Schouls LM., van Leeuwen WJ., Vandenbroucke-Grauls CMJE., Verhoef J., Mooi FR.: Molecular typing of methicillin-resistant Staphylococcus aureus on the basis of protein A gene polymorphism. European Journal of Clinical microbiology Infectious Diseases, 15, 60-64, 1996.

10. Golding GR, Bryden L, Levett PN, McDonald RR, Wong A, Wylie J, Graham MR, Tyler S, Van Domselaar G, Simor AE, Gravel D, Mulvey MR: Livestock-associated methicillin-resistant Staphylococcus aureus sequence type 398 in humans, Canada. Emerging Infectious Diseases, 16, 587-594, 2010.

11. Gordon RJ., Lowy FD.: Pathogenesis of methicillin-resistant Staphylococcus aureus infection. Clinical Infectious Diseases, 46, Suppl 5, 350-359, 2008.

12. Harmsen D., Claus H., Witte W., Rothgänger J., Claus H., Turnwald D., Vogel U.: Typing of methicillin-resistant Stapylococcus aureus in a university hospital setting by using novel software for spa repeat determination and database management. Journal of Clinical Microbiology, 41, 5442-5448, 2003.

13. Huang E, Gurzau AE, Hanson BM, Kates A, Smith TC, Pettigrew M, Spinu M, Rabinowitz PM: Detection of livestock-associated methicillin-resistant Staphylococcus aureus among swine workers n Romania. Journal of Infection and Public Health, 7, 323-332, 2014.

14. Huijsdens XW., van Dijke BJ., Spalburg E., van Santen-Verheuvel MG., Heck MEOC, Pluister GN, Voss A., Wannet WJB., de Neeling AJ: Community-acquired MRSA and pig-farming. Annals of Clinical Microbiology and Antimicrobials 5, 26, 2006, doi: 10.1186/1476-0711-5-26, http://www.annclinmicrob.com/content $/ 5 / 1 / 26$

15. Naimi TS., LeDell KH., Como-Sabetti K., Borchardt SM., Boxrud DJ., Etienne J., Johnson SK., Vandenesch F., Fridkin S., O’Boyle C., Danila RN., 
Lynfield R.: Comparison of community-and health care-associated methicillin-resistant Staphylococcus aureus infection. The Journal of the American Medical Association, 10, 2976-2984, 2003.

16. Oliveira DC, de Lencastre H: Multiplex PCR strategy for rapid identification of structural types and variants of the mec element in methicillin-resistant Staphylococcus aureus. Antimicrobial Agents and Chemotherapy, 46, 2155-2161, 2002.

17. Patchanee P, Tadee P, Arjkumpa O, Love D, Chanachai K, Alter T, Hinjoy S, Tharavichitkul P: Occurrence and characterization of livestock-associated methicillin-resistant Staphylococcus aureus in pig industries of northern Thailand. Journal of Veterinary Science, 15, 529-536, 2014.

18. Voss A., Loeffen F., Bakker J., Klaassen C., Wulf M.: Methicillin-resistant Staphylococcus aureus in pig farming. Emerging Infectious Diseases, 11, 1965-1966, 2003.

19. Zhang K., McClure JA., Elsayed S., Louie T., Conly JM.: Novel multiplex PCR assay for characterization and concomitant subtyping of staphylococcal cassette chromosome mec types I to V in methicillin-resistant Staphylococcus aureus. Journal of Clinical Microbiology, 43, 5026-5033, 2005.

Primljeno: 20.10.2016.

Odobreno: 25.12.2016. 